\title{
Critical Thinking Competence as Regard of Self-Concept and Gender Differences
}

\author{
Sadikin $^{1^{*}}$, Fahinu ${ }^{2}$, Ruslan $^{3}$ \\ ${ }^{1}$ Department of Mathematics Education, Lakidende University, Unaaha, Indonesia, 93461 \\ ${ }^{2}$ Department of Mathematics Education, Halu Oleo University, Kendari, Indonesia, 93132 \\ ${ }^{3}$ Department of Statistic, Halu Oleo University, Kendari, Indonesia, 93132 \\ *Corresponding author: sadikin_pmat13@yahoo.com
}

\section{ARTICLE HISTORY}

Received : 4 May 2018

Revised : 12 February 2019

Accepted : 18 March 2019

\section{KEYWORDS}

Critical Thinking in

Mathematics;

Self-Concept;

Gender;

\begin{abstract}
The study was a qualitative research that focused to describe students' critical thinking competence in mathematics. The subjects were six students from the X MIA-2 class of SMA 11 Kendari consisted of one male student categorized has a high self-concept, one male student categorized has a moderate self-concept, one male student categorized has a low self-concept, one female student categorized has a high self-concept, one female student categorized has a moderate self-concept, and one male student categorized has a low self-concept. In collecting data, the researcher used test instrument and questionnaire which were critical thinking competence test and self-concept questionnaire. Furthermore, the data collected were analyzed based on five phases of students' critical thinking ability in mathematics. The result of the study revealed that male students had better critical thinking abilities than female students. A better self-concept category will contribute to enhance student's critical thinking in mathematics.
\end{abstract}

\section{INTRODUCTION}

The ability of people to think critically is linked with their thinking competence (Yulianti, 2010: 98). Mathematics material and critical thinking ability are two things inseparable because mathematics material can be comprehended through critical thinking, and critical thinking can be trained through learning mathematics (Labertus cited in Fitriana, 2016: 2). Critical thinking is reasonable reflective thinking focused on deciding what to believe or do (Ennis, 1993: 180). Furthermore, Glazer (2001: 13) revealed that critical thinking in mathematics is the ability and disposition to incorporate prior knowledge, mathematical reasoning, and cognitive strategies to generalize, prove, or evaluate unfamiliar mathematical situations in a reflective manner. Critical thinking competence can also be identified as high order thinking ability that includes identifying problem, exploring, analyzing, clarifying, and until the proses of resulting. Hence it can be said that critical thinking ability is high order thinking activities (cognitive proses) to gain knowledge.

The this current research, researcher used five phases of critical thinking which are understanding an event, exploring, analyzing, clarifying and resulting. Understanding problem is an ability to identify to fulfill a premise or statement, and concepts needed to prove a statement. Exploring is an ability to construct meanings, to investigate mathematics ideas. Analyzing is an ability to create and decide mathematics ideas inductively and deductively. Clarifying is an ability to evaluate and explain, for instance, selecting mathematics ideas in contexts. Resulting skill is the ability to propose and improve mathematic statement through evident-based steps (Sadikin, 2016: 208).

Self-concept is defined as a disposition and attitude of people to themselves (Pamungkas, 2015: 56). Burn stated that self-concept as people's impression toward the overall performance of themselves, including their opinion about themselves, others' opinion toward them, and their own opinion to their achievements (Ghufron, 2010: 13). If a person's self-concept is considered good, then this person will have high self-confidence to achieve their success.

Calhoun and Acocella (cited in Ghufron, 2010: 17) stated that self-concept consists of three dimensions which are knowledge, hope and assessment. Knowledge is what a person knows about himself/herself. Hope is the view of what a person can achieve in the future. Assessment is the view of a person about himself/herself or it can be stated as pride.

In this research, the researcher utilized three dimensions of self-concept in mathematics which are students' knowledge about themselves, students' expectation in learning mathematics, and students' assessment of mathematics and its learning process. The researcher identifies students' ability to think critically in mathematics based on the self-concept and gender difference. This research aims to know and describe high school students' critical thinking ability in mathematics based on self-concept level and gender. Additionally, the result will be 
used as a valuable insight for school authority to evaluate the learning process in school.

\section{RESEARCH METHOD}

The research is a descriptive analysis. This research was conducted at SMAN 11 Kendari (public high school 11 Kendari) on 22 February 2018. Data were collected at X MIA-2 class of SMAN 11 Kendari. Subjects in this research were six students from X MIA-2 class, as described below:

Table 1. Subjects of research

\begin{tabular}{ccccc}
\hline No. & $\begin{array}{c}\text { Students } \\
\text { Initial }\end{array}$ & Gender & Code & $\begin{array}{c}\text { Self-Concept } \\
\text { Grade }\end{array}$ \\
\hline 1 & BN & Male & SL1 & 88 \\
\hline 2 & JCN & Female & SP1 & 85 \\
\hline 3 & ZF & Male & SL2 & 72 \\
\hline 4 & NF & Female & SP2 & 74 \\
\hline 5 & ASP & Male & SL3 & 58 \\
\hline 6 & VH & Female & SP3 & 58 \\
\hline
\end{tabular}

Data collection technique used in this research will be explained below:

\subsection{Test Method}

Test method was used to obtain data of students' critical thinking ability. The research subject spent 90 minutes to finish essay questions in mathematic. Furthermore, the students' answers were analyzed. The results were obtained in order to describe students' critical thinking ability in mathematics.

\subsection{Questionnaire Method}

Questionnaire method was used to get categories of students' self-concept data in the process of learning mathematics that consists of high, medium and low category. Scale of self-concept model used was Likert scale.

Data analysis technique used in this research is explained in the following points:

In analyzing data from mathematic questions was completed by referring to the five phases of critical thinking ability which are identifying problem, exploring, analyzing, clarifying, and resulting. These results were used to comprehend critical thinking ability in mathematics. Furthermore, the phases and indicators of students' critical thinking ability in regard to complete mathematics questions can be seen in the table below.

Table 2. The phases and indicators of students' critical thinking ability

\begin{tabular}{|c|c|c|c|}
\hline No. & Phase & Characteristic & Indicator \\
\hline 1 & $\begin{array}{c}\text { Identifying } \\
\text { problems }\end{array}$ & $\begin{array}{l}\text { Can identify the } \\
\text { paucity of premise } \\
\text { from a statement, } \\
\text { and concepts } \\
\text { needed in terms of } \\
\text { proving a statement }\end{array}$ & $\begin{array}{l}\text { Writing what is } \\
\text { known and } \\
\text { questioned from } \\
\text { the questions }\end{array}$ \\
\hline
\end{tabular}

\begin{tabular}{|c|c|c|c|}
\hline 2 & Exploring & $\begin{array}{c}\text { Can construct } \\
\text { meanings and } \\
\text { investigate } \\
\text { mathematics ideas }\end{array}$ & $\begin{array}{l}\text { Selecting concepts } \\
\text { to solve problems } \\
\text { accurately and } \\
\text { precisely }\end{array}$ \\
\hline 3 & Analyzing & $\begin{array}{c}\text { Can create and } \\
\text { decide mathematic } \\
\text { ideas inductively } \\
\text { and deductively }\end{array}$ & $\begin{array}{l}\text { Applying concepts } \\
\text { in order to utilize } \\
\text { mathematic model } \\
\text { in problem-solving }\end{array}$ \\
\hline 4 & Clarifying & $\begin{array}{c}\text { Can evaluate, } \\
\text { explain and } \\
\text { determine } \\
\text { mathematics ideas } \\
\text { in context }\end{array}$ & $\begin{array}{l}\text { Deciding a main } \\
\text { result and } \\
\text { procedure in order } \\
\text { to complete } \\
\text { problems / } \\
\text { selecting solution } \\
\text { or answer }\end{array}$ \\
\hline 5 & Resulting & $\begin{array}{c}\text { Can propose or } \\
\text { improve some steps } \\
\text { as evident in } \\
\text { mathematic } \\
\text { statements }\end{array}$ & $\begin{array}{l}\text { Re-examining } \\
\text { solution and } \\
\text { answer, then } \\
\text { deciding a } \\
\text { conclusion from a } \\
\text { problem }\end{array}$ \\
\hline
\end{tabular}

The data analysis of students' self-concept in this research has used a technique as the following:
High category
$=27 \% \times \mathrm{n}$ (for upper group)
Medium category
$=27 \% \times \mathrm{n}($ for medium group $)$
Low category
$=27 \% \times \mathrm{n}$ (for low group)

\section{RESULT AND ANALYSIS}

The subjects of research were taken by giving questionnaires to students of X MIA-2 class of SMA Negeri 11 Kendari. After collecting the data of self-concept, it was then analyzed. The researcher took six subjects which were consisted of a male who had a high self-concept grade namely subject SL1, a female student who had a high self-concept category which was SP1, a male student who had a medium self-concept category namely SL2, a female who had a medium self-concept category subject SP2, a male student who had a low self-concept category namely SL3, and a female student with a low self-concept category which was SP3. Furthermore, these six subjects were given a test about critical thinking ability in mathematics which aims to investigate high school students' critical thinking in mathematics based on the difference between both self-concept and gender.

The result from analysis of students' critical thinking ability in mathematics can be shown in the description below:

\subsection{Can Identify the Paucity of Premise from a Statement, and Concepts Needed in Terms of Proving a Statement}

SL1: can identify overall information and problems by writing what was known and asked.

SP1: can identify overall information and problems by writing what was known and asked.

SL2: can identify half information and problems by writing what was known and asked.

SP2: can identify half information and problems by writing what was known and asked.

SL3: can identify half information and problems by writing what was known and asked.

SP3: barely can identify information and problems, as a result, 
the student could not write what was known and asked accurately.

\subsection{Can Construct Meanings and Investigate Mathematic Ideas}

SL1: can select concept in order to solve problems clearly and precisely.

SP1: can to select concept in order to solve problems clearly and precisely.

SL2: can select half concept in order to complete problems.

SP2: barely can select concept in order to complete problems.

SL3: select concept in order to complete problems with bias (prejudice).

SP3: cannot select concept in order to complete problems.

\subsection{Can Create and Decide Mathematic Ideas Inductively and Deductively}

SL1: can apply concept of mathematic model in order to complete problems.

SP1: can apply half concept by creating mathematic model in order to complete problems.

SL2: can apply concept by creating mathematic model in order to complete problems.

SP2: cannot accurately apply half concept by creating mathematic model in order to complete problems.

SL3: apply concept by creating mathematic model in order to complete problems with bias (prejudice).

SP3: cannot apply concept, as a result, the student could not create mathematic model.

\subsection{Can Evaluate, Explain and Select Mathematics Ideas in Contexts}

SL1: can show main result and procedure in terms of completing problem/selecting solutions/answers accurately.

SP1: can show half of main result and procedure in terms of solving problems/selecting solutions/answers.

SL2: cannot accurately show main result and procedure in order to complete problems/selecting answer and solution.

SP2: cannot accurately show main result and procedure in order to complete problems/selecting answer and solution.

SL3: show main result and procedure in order to complete problems/ selecting solutions/ answers with bias (prejudice). SP3: show main result and procedure in order to complete problems/ selecting solutions/ answers with bias (prejudice).

\subsection{Can Propose or Improve Some Steps as Evident of Mathematic Statements}

SL1: can examine half solution/answer and select conclusion based on a problem.

SP1: can examine half solution/ answer and select conclusion based on a problem.

SL2: cannot accurately re-examine solution/ answer and select conclusion based on a problem.

SP2: re-examine solution/ answer and select conclusion based on a problem with bias (prejudice).

SL3: cannot re-examine solution/answer and select conclusion based on a problem.

SP3: cannot re-examine solution/answer and select conclusion based on a problem.

\section{CONCLUSION}

Based on the data analysis and discussion, conclusions are explained as the following:

\subsection{Critical Thinking Ability of Male Student on Mathematic Who Has a High Self-Concept Category (SL1)}

SL1 can identify overall information and problems by writing what are known and asked, can determine concept by selecting problems clearly and accurately, can apply concept by creating mathematic model in order to complete problems, can show main result and procedure in terms of solving problems/selecting solution/answer precisely, and can examine half solution/answer and determine conclusion of a problem.

\subsection{Critical Thinking Ability of Female Student On Mathematic Who Has a High Self-Concept Category (SP1)}

SP1 can identify overall information and problems by writing what are known and asked, can determine concept by selecting problems clearly and accurately, can apply concept by creating mathematic model in order to complete problems, can show main result and procedure in terms of solving problems/selecting solution/answer precisely, and can examine half solution/answer and determine conclusion of a problem.

\subsection{Critical Thinking Ability of Male Student on Mathematic Who Has a Medium Self-Concept Category (SL2)}

SL2 can identify half information and problems by writing what are known and asked, can determine half concept by selecting problems clearly and accurately, can apply concept by creating mathematic model in order to complete problems, cannot accurately show main result and procedure in terms of solving problems/selecting solution/answer, and cannot accurately examine half solution/answer and determine conclusion of a problem.

\subsection{Critical Thinking Ability of Female Student on Mathematic Who Has a Medium Self-Concept Category (SP2)}

SP2 can identify half information and problems by writing what are known and asked, cannot accurately determine concept by solving problems, cannot accurately apply half concept by creating mathematic model in order to complete problems, cannot accurately show main result and procedure in terms of solving problems/selecting solution/answer, and can re-examine solution/answer and determine conclusion of a problem with bias (prejudice).

\subsection{Critical Thinking Ability of Male Student on Mathematic Who Has a Low Self-Concept Category (SL3)}

SL3 can identify half information and problems by writing what are known and asked, can determine concept by solving problems with bias (prejudice), can apply concept by creating mathematic model in order to complete problems with bias 
(prejudice), can show main result and procedure in terms of solving problems/selecting solution/answer with bias (prejudice), and cannot re-examine solution/answer and determine conclusion of a problem.

\subsection{Critical Thinking Ability of Female Student on Mathematic Who Has a Low Self-Concept Category (SP3)}

SP3 cannot accurately identify information and problems as a result could not write what are known and asked, cannot determine concept by solving problems, cannot apply concept resulting the student could not create mathematic, can show main result and procedure in terms of solving problems/selecting solution/answer with bias (prejudice), and cannot re-examine solution/answer and determine conclusion of a problem.

\section{SUGGESTION}

Based on the result and conclusion of this research, therefore, it can offer some suggestions such as:

Teacher should regularly provide essay questions to identify students' critical thinking ability in mathematics, which aims to train their thinking.

In order to obtain a more robust research related to the current research, therefore, it is highly recommended to examine the weaknesses of this research to minimize the negative effects for future study.

\section{ACKNOWLEDGEMENTS}

I acknowledged Allah Subhanahu wa Ta'ala, Rasulullah Shallallahu 'alaihi wa Sallam, my family, Department of Mathematics Education, Lakidende University, and others who have helped in the preparation of this paper.

\section{REFERENCES}

Ennis, R. H. (2001). Critical Thinking Assessment. Theory into Practice: Teaching for Higher Order Thinking, 32(3), 179-186.

Fitriana, D., Yusuf, M., \& Susanti, E. (2016). Pengembangan Lembar Kerja Siswa Menggunakan Pendekatan Saintifik untuk Melihat Berpikir Kritis Siswa Materi Perbandingan. Jurnal Pendidikan Matematika, 10(2), 1-16.

Ghufron, M. N., \& Risnawati. (2011). Konsep Diri. In Teori-Teori Psikologi, (pp. 13-20). Jogjakarta: Ar-Ruzz Media.

Glazer, E. (2001). Using Critical Thinking Skills in Mathematics. In Using Internet Primary Sources to Teach Critical Thinking Skills in Mathematics. (pp. 13-25). London: Greendwood Press.

Pamungkas, A. S. (2015). Kontribusi Self Concept Matematis dan Mathematics Anxiety terhadap Hasil Belajar Mahasiswa. Jurnal Dinamika Pendidikan, 8(2), 55-60.

Sadikin, Fahinu, Ruslan, \& Kadir. (2016, October). Effect of Application of Learning Model Group Investigation on Critical Thinking Ability of Mathematical High School Students. Proccedings Internasional Seminar on MSCEIS 2016, (pp. 208-212). FMIPA UPI Bandung.

Yulianti, Zulkardi, \& Putri, R. I. I. (2010). Pengembangan Perangkat Pembelajaran Peluang Berbasis Reciprocal Teaching untuk Melatih Kemampuan Berpikir Kritis Siswa Kelas XI SMA Negeri 3 Lubuklinggau. Jurnal Pendidikan Matematika, 4(2), 97-113. 